\title{
High concentration of coagulase-negative staphylococci carriage among bioaerosols of henhouses in Central China
}

\author{
Yuanqing Lư ${ }^{\dagger}$ Qin Lư ${ }^{\dagger}$ Yiluo Cheng, Guoyuan Wen, Qingping Luo, Huabin Shao and Tengfei Zhang*
}

\begin{abstract}
Background: Coagulase-negative staphylococci (CoNS) are a group of opportunistic pathogens, which are widely spread in the environment. Animal breeding is an important source of pathogen spreading. However, the concentration and characteristics of CoNS in the bioaerosols of henhouses are unclear.

Results: In this study, we showed that CoNS were significantly increased in bioaerosols of henhouses during the first 60 days, and reached $2.0 \times 10^{6} \mathrm{CFU} / \mathrm{m}^{3}$, which account for $75.4 \%$ of total bacteria. One hundred and two CoNS isolates from bioaerosols and nasal swabs of farmers were further identified, covering seven species. Among these, $41.2 \%$ isolates were Staphylococcus sciuri, which was the predominant species, followed by S. equorum, S. saprophyticus, S. haemolyticus, S. xylosus, S. arlettae and S. gallinarum. There were high rates of resistance to oxacillin in CoNS (49.0\%), which were defined as Methicillin-Resistant CoNS (MRCoNS), and 36.3\% isolates contained resistance gene mecA. Bioaerosol infection models showed that, chickens exposed to aerosolized S. sciuri had significant induction of inflammatory cytokines interleukin (IL)-1 $\beta$, IL-6, IL-8 and IL-10 at 5 days post-infection (dpi) in lungs and at $7 \mathrm{dpi}$ in spleens.
\end{abstract}

Conclusions: We reported a high concentration of CoNS in henhouses, and S. sciuri was the preponderant CoNS species. Antibiotic resistance analysis and bioaerosols infection of CoNS further highlighted its hazards on resistance and immunological challenge. These results suggested that, CoNS in bioaerosols could be one serious factor in the henhouses for not only poultry industry but also public health.

Keywords: Bioaerosol, Coagulase-negative staphylococci, Antibiotic resistance, mecA, Inflammatory cytokine

\section{Background}

Coagulase-negative staphylococci (CoNS) are a group of opportunistic pathogens, which are not only in animals and humans but also widely spread in the environment, such as dust, soil, water and air [1-3]. CoNS can cause human and animal infections. In humans, CoNS are associated with endocarditis, septicemia and blood stream infection, and they have become one of the most important sources of hospital infection [4, 5]. In chickens, CoNS infection can cause arthritis, fibrinopurulent blepharitis and even systemic infection [6-8]. In addition, methicillin-resistant CoNS (MRCoNS)-

\footnotetext{
*Correspondence: tfzhang23@163.com

†Yuanqing Lu and Qin Lu contributed equally to this work.

Key laboratory of prevention and control agents for animal bacteriosis,

Institute of Animal Husbandry and Veterinary, Hubei Academy of Agricultural Sciences, Wuhan 430064, China
}

contaminated chicken meat is frequently reported, suggesting foodborne transmission of the bacteria $[9,10]$.

Recently, the reports on multi-resistant CoNS were increasing, with the increase in antibiotic usage [11]. The increasing antibiotic resistance of CoNS also limits the drug choices for treatment of CoNS infections [12]. What is more, CoNS exist in the places where antibiotics are widely used, such as hospitals and animal farms [13, 14], which accelerate the spread of resistance genes. Methicillin-resistant Staphylococcus aureus (MRSA) and vancomycin-resistant $S$. aureus (VRSA) have been frequently reported $[15,16]$, and show similar resistance genes to CoNS, such as the methicillin-resistance gene $m e c A$ [17]. As a widespread bacterium in the environment, CoNS has been considered as a reservoir of resistance genes, which highlights its threat to public health.

(c) The Author(s). 2020 Open Access This article is distributed under the terms of the Creative Commons Attribution 4.0 International License (http://creativecommons.org/licenses/by/4.0/), which permits unrestricted use, distribution, and 
Bioaerosols, mainly including bacteria, viruses and fungi, are potential environmental sources of animals and human infection. For animals, piglets exposed to $10^{6} \mathrm{cfu} / \mathrm{m}^{3}$ MRSA in the air were persistent colonized and $10^{4} \mathrm{cfu} / \mathrm{m}^{3}$ were transient [18]. MRCoNS carriage analysis suggested potential transmission of MRCoNS from livestock to humans by occupational livestock contact [19]. In poultry houses, bioaerosol is one important route of transmission of viral as well as bacterial pathogens. In Switzerland, an analysis on 12 poultry houses showed that the mean bacterial exposure level to poultry farmers was $53 \times 10^{7}$ cells $/ \mathrm{m}^{3}$, and among them, $62 \times 10^{6}$ cells $/ \mathrm{m}^{3}$ were staphylococci [20]. In Canada, Enterococcus spp., Escherichia coli, and Staphylococcus spp. spread widely in bioaerosols of poultry houses, and high levels of zinc bacitracin, erythromycin and tetracycline resistance genes have been found in bioaerosols [21]. Therefore, bioaerosols in animal houses are potentially harmful to the health of both animals and farmers. In addition, besides livestock manure and waste water, bioaerosol is another important pathway for diffusing pathogens and resistance genes to the outside environment.

The goal of this study was to investigate the concentration and antibiotic resistance of CoNS in bioaerosols from henhouses in China, and further examine its effect on immune response of chickens. This study will provide important information for the poultry industry and public health.

\section{Results}

\section{CoNS in bioaerosols and farmers}

Bioaerosol samples were collected from nine henhouses covered the first 90 days of the growing period before changing their cage. As shown in Fig. 1, at day 2, the mean total bacterial count was $7.8 \times 10^{4} \mathrm{cfu} / \mathrm{m}^{3}$ in the bioaerosols of henhouses, and among them, the mean of
CoNS was $1.7 \times 10^{3} \mathrm{cfu} / \mathrm{m}^{3}$, which accounted for approximately $2.2 \%$ of total bacteria. As time progressed, the total bacterial count, especially the total CoNS count, was significantly increased during the first 60 days. At day 60 , the mean total bacterial count was $2.6 \times$ $10^{6} \mathrm{cfu} / \mathrm{m}^{3}$, which was approximately 34 -fold of that at day 2 , and among them, $75.4 \%\left(2.0 \times 10^{6} \mathrm{cfu} / \mathrm{m}^{3}\right)$ of bacteria were CoNS. At day 90, the bacterial count was similar to that at day $60(p>0.05)$. These results suggested that CoNS was the primary genus in the bioaerosols of henhouses. In addition, nasal swabs from 14 poultry farmers were also evaluated, and among them, eight (57.1\%) samples were CoNS-positive.

To characterize further the CoNS in bioaerosols and farmers, 102 CoNS were randomly picked and further identified. As shown in Table 1, 102 isolates covered seven species. Forty-two (41.2\%) isolates were S. sciuri, which was the predominant species, followed by $S$. equorum (21.6\%), S. saprophyticus (18.6\%) and S. haemolyticus (10.8\%). The others included S. xylosus (5.9\%), S. arlettae (1.0\%) and S. gallinarum (1.0\%). Among them, five S. sciuri, two S. equorum and one S. haemolyticus isolates were from nasal swabs of farmers.

\section{Presence of mecA and antibiotic resistance rates in CoNS}

The susceptibility of CoNS isolates to nine antibiotics was tested using disk diffusion assays (Fig. 2). The isolates showed high resistance rates to antibiotics that are widely used in animal breeding, including penicillin (69.61\%), ampicillin (58.82\%), ciprofloxacin (66.67\%), chloramphenicol (93.14\%), erythromycin (48.04\%), tetracycline (91.18\%) and clindamycin (45.10\%). In contrast, lower resistance rates were seen for amikacin (6.86\%) and rifampicin (20.59\%), which are less used in breeding. Susceptibility to oxacillin and vancomycin, which are two important antibiotics used in human, were tested using MIC assays (Table 2). The MICs of oxacillin in $49.0 \%$ isolates were >

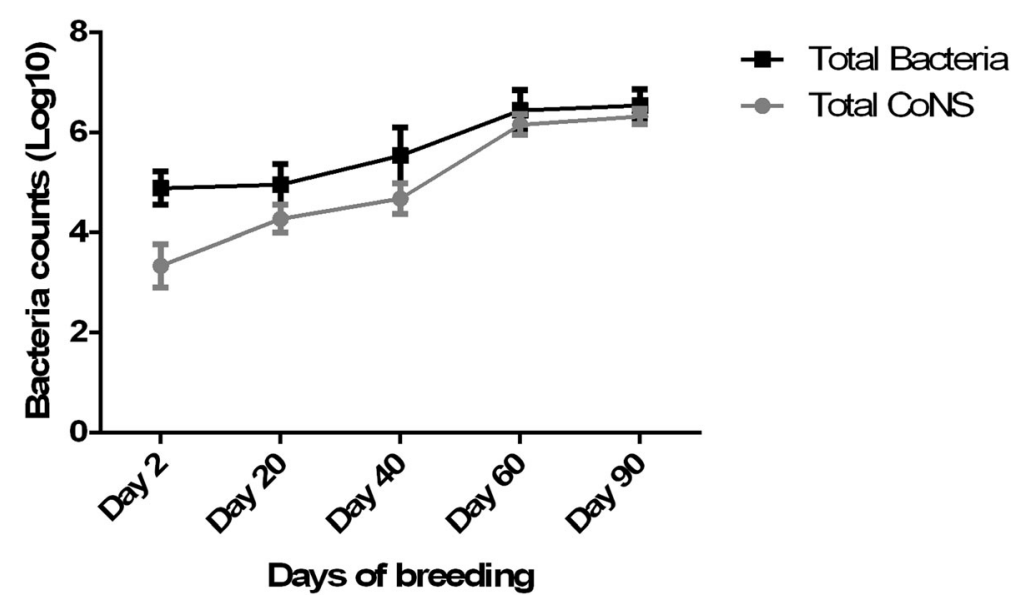

Fig. 1 Increasing of total bacteria and CoNS during chicken breeding 
Table 1 The distribution of mecA in different species of CoNS strains

\begin{tabular}{|c|c|c|c|c|}
\hline Species & No. of strains & Proportions in CoNS & No. of mecA positive strains & mecA Positive rates \\
\hline S. equorum & $22(2)^{a}$ & $21.57 \%$ & $4(1)$ & $18.18 \%$ \\
\hline S. haemolyticus & $11(1)$ & $10.78 \%$ & 0 & $0.00 \%$ \\
\hline S. saprophyticus & 19 & $18.63 \%$ & 0 & $0.00 \%$ \\
\hline S. sciuri & $42(5)$ & $41.18 \%$ & $30(2)$ & $71.43 \%$ \\
\hline S. xylosus & 6 & $5.88 \%$ & 2 & $33.33 \%$ \\
\hline S. arlettae & 1 & $0.98 \%$ & 0 & $0.00 \%$ \\
\hline S. gallinarum & 1 & $0.98 \%$ & 1 & $100.00 \%$ \\
\hline Total & $102(8)$ & $100.00 \%$ & $37(3)$ & $36.27 \%$ \\
\hline
\end{tabular}

${ }^{a}$ The No. in the brackets indicate the number of isolates from the nasal swabs of farmers

$2 \mu \mathrm{g} / \mathrm{ml}$, including all of the $m e c A$-positive isolates and $20 \%$ $(13 / 65) m e c A$-negative isolates. The MICs of vancomycin in $40.2 \%$ isolates were between 4 and $8 \mu \mathrm{g} / \mathrm{ml}$, which were intermediate. Compared with $m e c A$-negative isolates, $m e c A$-positive isolates showed higher resistance rates to oxacillin, penicillin, ampicillin and ciprofloxacin, but lower resistance rates to erythromycin and clindamycin $(p<0.05)$.

The presence of $m e c A$ was screened by PCR in all the CoNS isolates. As shown in Table 1, 36.3\% isolates (34 isolates from bioaerosols and three from nasal swabs of farmers) were found to contain $m e c A$ gene. Among these $m e c A$-positive CoNS isolates, 30 (two from nasal swabs of farmers) were S. sciuri, accounting for $71.4 \%$ of total S. sciuri isolates, followed by $S$. equorum (four isolates, one from nasal swab of farmer), S. xylosus (two isolates) and S. gallinarum (one isolate). In contrast, mecA was not found in S. saprophyticus, $S$. haemolyticus and $S$. arlettae isolates. The results suggested that mecA was wide spread in CoNS, especially $S$. sciuri, in henhouses.

Inflammatory response induced by aerosolized MRCoNS in chickens

As above described, the concentration of CoNS could reach $10^{6}$ magnitudes $\mathrm{cfu} / \mathrm{m}^{3}$ in henhouses, so we chose approximately $1.0 \times 10^{6} \mathrm{cfu} / \mathrm{m}^{3}$ as the concentration of exposure with aerosolized MRCoNS ( $m e c A$ positive $S$ sciuri). As shown in Fig. 3, although there were no typical symptoms after infection, the expression of proinflammatory cytokines IL-1 $\beta$, IL- 6 and IL8 were significantly induced at $5 \mathrm{dpi}$ in lungs and at $7 \mathrm{dpi}$ in spleen, and at the same time, the expression of anti-inflammatory cytokine IL-10 was also induced. Then, IL-1 $\beta$, IL-6, IL-8 and IL-10 were reduced at 14 dpi. The expression of TNF- $\alpha$ was not greatly induced by aerosolized MRCoNS. These results suggested that aerosolized MRCoNS induced inflammatory cytokines in chickens.

\section{Discussion}

In this study, we showed that CoNS were highly prevalent, and they were the dominant cultivable bacterial group under aerobic condition in bioaerosols in the later period of chicken breeding. In addition, CoNS were isolated from bioaerosols and farmers, and further characterized by species, antibiotic resistance, and poultry infection.

In recent decades, intensive animal production has become common, but it followed environmental concerns

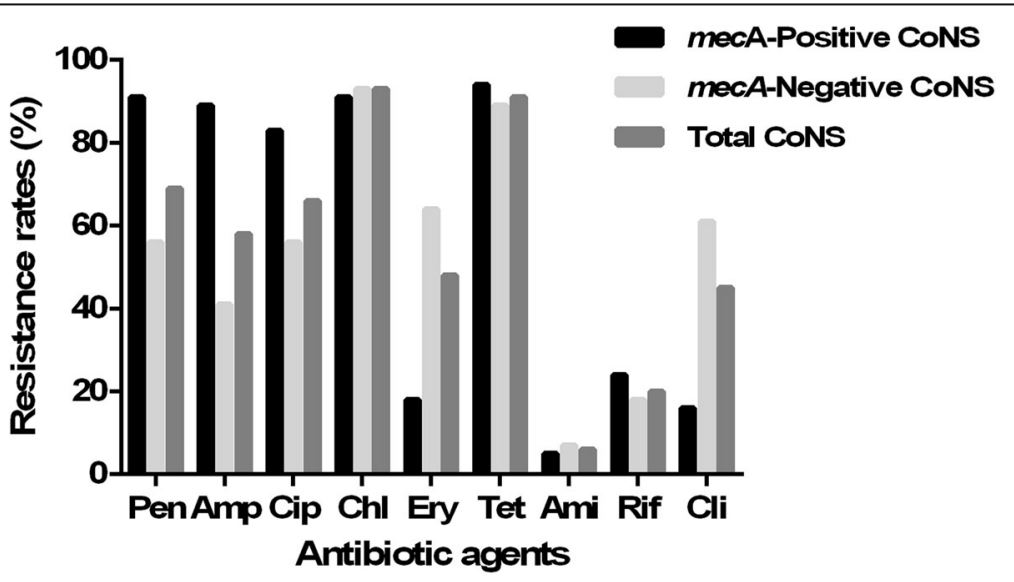

Fig. 2 Antibiotic resistance of CoNS to nine drugs 
Table 2 Distribution of CoNS isolates in different MICs

\begin{tabular}{|c|c|c|c|c|c|c|c|}
\hline \multirow[t]{2}{*}{ No. of isolates } & \multicolumn{4}{|c|}{ MICs of oxacillin } & \multicolumn{3}{|c|}{ MICs of vancomycin } \\
\hline & $\leq 0.25$ & 0.5 & 1 & $\overline{\geq 2}$ & $\overline{\leq 2}$ & $4-8$ & $\geq 16$ \\
\hline mecA-positive CoNS $(n=37)$ & 0 & 0 & 0 & 37 & 25 & 12 & 0 \\
\hline mecA-negative $\operatorname{CoNS}(n=65)$ & 8 & 31 & 13 & 13 & 36 & 29 & 0 \\
\hline
\end{tabular}

and public health, and bioaerosols contamination is one of the important risk factors [22]. Various bacteria have been identified in bioaerosols from animal houses, such as Pseudomonas, Bacillus, Salmonella, E. coli, Streptococcus and Staphylococcus [23]. The composition of bioaerosols in different animal houses shows different features. For example, the mean total concentration of bacteria inside swine barns was $6.6 \times 10^{4} \mathrm{cfu} / \mathrm{m}^{3}$, mainly including Staphylococcus, Pseudomonas and
Bacillus [24]. During cattle breeding, bioaerosols are the most important route of transmission for Mycoplasma bovis [25]. In hospitals, Staphylococcus, including S. aureus and CoNS, is one of the most serious bacteria in bioaerosols. Several studies on the bioaerosols of poultry houses have been done. In Switzerland, the mean bacterial exposure level to poultry farmers was $53 \times 10^{7}$ cells $/ \mathrm{m}^{3}$, and among them, $62 \times 10^{6}$ cells $/ \mathrm{m}^{3}$ were staphylococci [20]. In Australia and Poland, staphylococci was also one of the dominant bacteria in the poultry houses [26, 27] Even in some broiler houses of Germany, staphylococci concentrations were higher than between $1 \times$ $10^{6} \mathrm{cfu} / \mathrm{m}^{3}$, and affected by the wind in the barn [28]. Besides to staphylococci, potential pathogens, such as Enterococcus spp., Escherichia coli and Salmonella
A
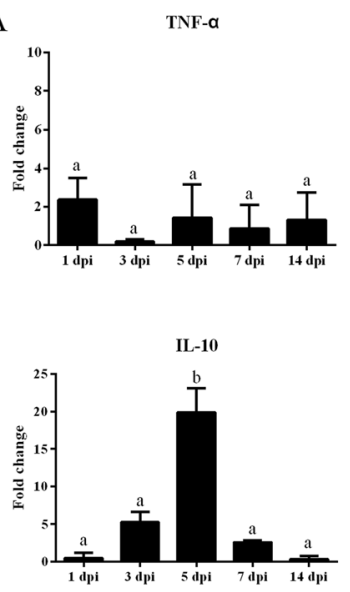

B
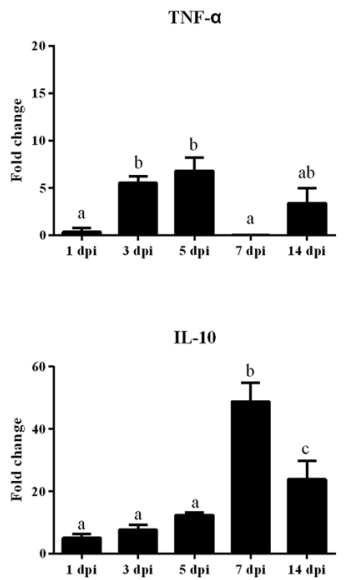
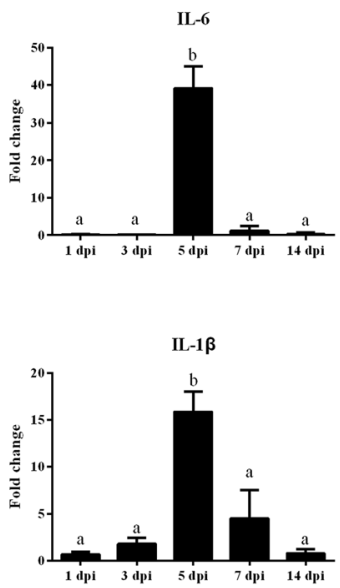

Lung
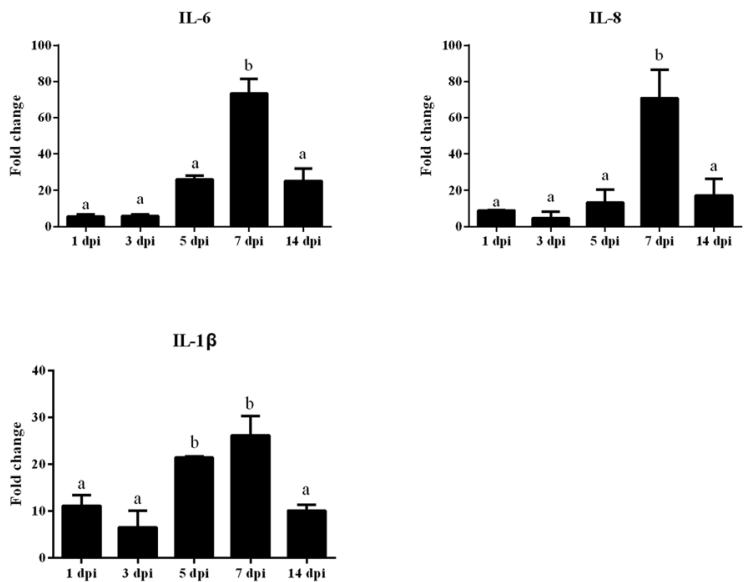

Spleen

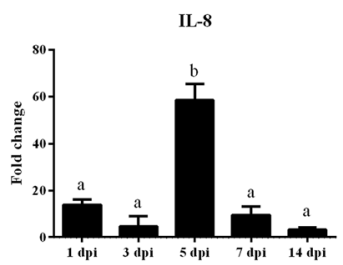


spp., were also found in poultry houses [21, 29]. However, the knowledge on the concentration and characterization of CoNS in henhouses was still limited.

We investigated the bacteria in bioaerosol began with breeding of 1 day old chicken. Compared with membrane filtration and impaction, we could see different sampling procedures had obvious influences on the results, and two samplers, the Andersen 6-stage sampler and the All glass impinger-30 (AGI-30), were recommended as standards for sampling of microbiological aerosols: $[24,30]$. In this study, we chose SKC BioSampler, which is All-Glass-Impinger for sampling. Our results showed that the total bacterial counts, especially the CoNS counts, were significantly increased during breeding. Especially in the later period in our tests, $75.4 \%$ of bacteria in bioaerosols were CoNS. These results suggested that CoNS were the dominant bacterial group in the bioaerosols of henhouses. CoNS can colonize well on the surface of animal skin and have biofilm forming ability to resist environmental stresses [31], and these phenotypes help them to survive and spread in the bioaerosols. Compared with swine houses, that the overall mean total concentrations of cultivable bacteria inside the barns were $8.6 \times 10^{4} \mathrm{cfu} / \mathrm{m}^{3}$ as measured by impaction [24], higher concentrations of bacteria in bioaerosols were found in chicken houses, and wingfanning of chickens might be an important reason.

Seven species of CoNS were identified in bioaerosols and nasal swabs of farmers, and S. sciuri was the predominant species, which was consistent with the incidence in other environments of chicken breeding, like bedding and litter [32,33]. Among our identified species, S. saprophyticus and S. haemolyticus were frequently recovered from humans. In the previous study, the CoNS were recovered from chicken and their carcasses, minced meat and the contact persons, suggesting its potential transmission from animal to humans [34]. Most human infections caused by CoNS are subacute and chronic [35], but sometimes, foreign-body-related infections of the bloodstream by CoNS can be fatal [36, 37]. As opportunistic pathogens, the presences of high concentrations of CoNS in bioaerosols have a potential risk of disease for chickens as well as poultry farmers.

Antibiotic resistance and resistance transmission of CoNS in bioaerosols is another important risk factor, for not only poultry industry but also public health. According to previous reports, hospital-acquired MRSA is often multidrug resistant, while community-acquired MRSA strains are usually limited to beta-lactam resistance and are susceptible to fluoroquinolones, aminoglycosides, erythromycin, and clindamycin $[38,39]$. In contrast, the staphylococci from animal breeding have different resistance patterns [40]. Our CoNS isolates showed high resistance rates to penicillin, ampicillin, ciprofloxacin, chloramphenicol and tetracycline, which were used in animal breeding, suggesting the importance of selection stress from antibiotics. In addition, 49.0\% CoNS isolates were MRCoNS (MIC $\geq 2$ ), and among them, $74 \%$ contains mecA, which was responsible for its resistance. $S$. aureus is one of the most important pathogens for human and animals and widely exist in poultry breeding [41]. MRSA, which contains the horizontally transferable methicillin-resistance gene mecA, was a global risk to human health [17]. Because CoNS is a closely related staphylococci of $S$. aureus, it is considered as an important resistance determinants provider of $S$. aureus. In this study, high percentage of CoNS isolates (36.3\%) contained mecA gene, and this is of concern of potential spread of mecA to $S$. aureus in the henhouses. What was more serious, lots of MRCoNS isolates were not susceptive to vancomycin, which was the gold standard for treating the infections of methicillin-resistant staphylococci [42]. Therefore, these isolates had more broadspectrum resistance, that suggested the emergence of multi-drug resistant CoNS in the bioaerosols of poultry houses. In addition, it has been proved that bacteria, such as $E$. coli carrying plasmid-mediated quinolone resistance genes, could spread from farms to the external environment via air [43]. In this study, although we did not test the CoNS around the henhouses, we suppose that the multi-drug resistant CoNS can spread out from the inside of henhouses to the outside through the air, which further highlight its serious threat to public health.

CoNS are the predominant pathogens causing intramammary infections in dairy cows [14], while in chickens, the economic burden of staphylococcal infections includes decreased weight gain, drop in egg production, mortality, condemnation at slaughter and lameness [33]. Although obvious symptoms caused by CoNS did not occurred frequently, immunological challenge from CoNS bioaerosol was one of the important negative effects in chickens. To simulate the CoNS bioaerosols infection, we chose mecA-positive $S$. sciuri, which was the predominant species in the henhouses, as the model of aerosolized bacteria, and we chose $1.0 \times 10^{6} \mathrm{cfu} / \mathrm{m}^{3}$, which was the detected concentration in this study, as the concentration of exposure. As shown in Fig. 3, although there were no typical symptoms caused by independent CoNS infection, proinflammatory cytokines including IL-1 $\beta$, IL- 6 and IL- 8 were significantly induced at 5 or $7 \mathrm{dpi}$, and at the same time anti-inflammatory cytokine IL-10 was also up-regulated. Both of them were reduced at $14 \mathrm{dpi}$ to maintain a homeostatic state. These results suggest that exposure in aerosolized CoNS could induce obvious inflammatory response in chickens. It is evident that the inflammatory process is a life-saving response to microbial challenge, however, it is supported 
by available nutrients diverted from productive purposes $[44,45]$. As previously reported, equalized for feed intake, a vigorous acute phase immune response in chickens has been estimated to account for around 10\% of nutrient use [46], and the threonine requirement increase by 2 to 10\% [47]. A general model for predicting animal performance during pathogen challenges suggested that, subclinical infections, even with no visible symptoms but immune responses, caused a reduction in feed intake, and greater reduction was seen during clinical disease [48]. Therefore, the induction of inflammatory cytokines by CoNS suggested that, continuous exposure to high concentration of CoNS had caused subclinical infection of chickens, which could lead to reduced production performance. In addition, CoNS were also isolated in the nasal swabs of poultry farmers, which suggested that the presence of CoNS in bioaerosols might represent a significant immunological challenge to chickens as well as farmers.

\section{Conclusions}

In this study, we showed high concentration of CoNS in henhouses, and S. sciuri was the preponderant CoNS species. Antibiotic resistance analysis and bioaerosols infection of CoNS further highlighted its hazards on resistance and immunological challenge. These results suggested that, CoNS in bioaerosols could be a serious factor in the henhouses for not only poultry industry but also public health.

\section{Methods}

\section{Sampling from the henhouses}

Bioaerosol samples were collected from nine henhouses for the growing period of caged Hy-Line Layers in Central China during April to July 2017 and 2018. The sampling times covered the first 90 days of the growing period before changing their cage (chickens age 2, 20, 40, 60 and 90 days). All the houses were strictly disinfected before breeding. The used sampler was SKC BioSampler (SKC, Pittsburgh, PA, USA) and the flow rate was $12.5 \mathrm{~L} / \mathrm{min}$. According to the indoor air quality standard in China (GB/ T18883-2002), bioaerosols were collected at five sampling sites, which were evenly distributed in the henhouses. At each sampling site, the sampling time was $20 \mathrm{~min}$ and a total of $250 \mathrm{~L}$ bioaerosols were collected into $20 \mathrm{ml}$ phosphate-buffered saline (PBS). The collected samples were kept in $50 \mathrm{ml}$ sterile centrifuge tubes in an ice bath and then transferred to the laboratory for analysis immediately. Nasal swabs of farmers in each henhouse were also collected and transported to the laboratory for bacterial isolation.

\section{Enumeration, isolation and identification of staphylococci} in bioaerosols

To count the total culturable bacteria and staphylococci from bioaerosols, the samples in PBS were 10-fold serial diluted, and spread onto Tryptic Soy Agar (TSA) (BD, Franklin Lakes, NJ, USA) plates and Baird Parker plates (BD) at $37^{\circ} \mathrm{C}$ for $24 \mathrm{~h}$. The suspect staphylococcal colonies on the Baird Parker plates were confirmed by Gram stain and PCR targeting the Staphylococcus-specific 16S rRNA fragment as previously described [49]. The bacterial count in each henhouse was calculated as the mean from five sampling sites. To further isolate and identify the species of staphylococci, three to four suspect colonies from each plate were picked randomly and identified using 16S rRNA sequence analysis and Microbiology Identification System Phoenix-100 (BD). To isolate and identify the staphylococci from poultry farmers, the collected nasal swabs were streaked onto Baird Parker plates and cultured at $37^{\circ} \mathrm{C}$ for $24 \mathrm{~h}$, and the suspect staphylococcal colonies were identified as described above.

\section{Antibiotic susceptibility testing}

CoNS isolates were tested for susceptibility to antimicrobial drugs using disk diffusion assay or minimum inhibitory concentration (MIC) assay according to the Clinical and Laboratory Standards Institute (CLSI) [50]. Disks were placed on the surfaces of CoNS inoculated Mueller Hinton agar plates (Oxoid, Basingstoke, UK). These antimicrobial disks (Oxoid) included penicillin (Pen, $10 \mathrm{U}$ ), ampicillin (Amp, $10 \mu \mathrm{g}$ ), ciprofloxacin (Cip, $5 \mu \mathrm{g}$ ), chloramphenicol (Chl, $30 \mu \mathrm{g}$ ), erythromycin (Ery, $15 \mu \mathrm{g}$ ), tetracycline (Tet, $30 \mu \mathrm{g}$ ), amikacin (Ami, $30 \mu \mathrm{g}$ ), rifampicin (Rif, $5 \mu \mathrm{g}$ ) and clindamycin (Cli, $2 \mu \mathrm{g}$ ). Inoculated plates were incubated at $37^{\circ} \mathrm{C}$ for $24 \mathrm{~h}$. The inhibition zone diameters were measured and interpreted following the CLSI guidelines. MIC assays were carried out to determine the susceptibility of CoNS to oxacillin (used for confirmation of methicillin resistance in CoNS, CLSI) and vancomycin, and the evaluated concentrations were $0.125-128 \mu \mathrm{g} / \mathrm{ml}$ for oxacillin and $0.125-16 \mu \mathrm{g} / \mathrm{ml}$ for vancomycin. E. coli ATCC 25922 and S. aureus ATCC 25923 strains were included in the test for quality control.

\section{Detection of mecA in CoNS}

Genomic DNA was extracted using MiniBEST Universal Genomic DNA Extraction Kit (TaKaRa). The presence of $m e c A$ was detected using PCR targeting the fragment of mecA (163 bp), as previously reported [51]. PCR was performed in a GeneAmp PCR System 9700 (ABI, Darmstadt, Germany). The primers were mecAF, 5'-ACTGCTATCC ACCCTCAAAC-3' and mecAR, 5'-CTGGTGAAGT TGTAATCTG-3'. The reaction conditions were as 
followed: initial denaturation temperature of $94{ }^{\circ} \mathrm{C}$ for 5 min, followed by 35 cycles of denaturation at $94^{\circ} \mathrm{C}$ for 30 s, renaturation at $55^{\circ} \mathrm{C}$ for $1 \mathrm{~min}$, elongation at $72^{\circ} \mathrm{C}$ for $30 \mathrm{~s}$ and final elongation at $72^{\circ} \mathrm{C}$ for $5 \mathrm{~min}$. The PCR products were subject to agarose gel electrophoresis. The DNA bands were stained with ethidium bromide and visualized using a GelDoc XR System (Bio-Rad, Shanghai, China).

\section{Immune responses of chickens infected with aerosolized CoNS}

To investigate the effects of chickens exposed to aerosolized CoNS, bioaerosol infection was carried out. Embryonated eggs from SPF Leghorn chickens were purchased from Merial-Vital, Beijing, China. SPF chickens were hatched in a contained environment, and raised in negative pressure isolators for animal work. A total of 40 1-day-old SPF chickens were randomly divided into two groups $(n=20)$. Chickens in the infection group were exposed to bioaerosols containing approximately $10^{6} \mathrm{cfu} / \mathrm{m}^{3}$ mecA-positive $S$. sciuri for $1 \mathrm{~h}$ (range from $6 \times 10^{5}$ to $2.5 \times 10^{6} \mathrm{cfu} / \mathrm{m}^{3}$ during this hour), and were transferred into individually ventilated cages for breeding. Aerosolized bacteria were exported by Atomizer Aerosol Generator Model 3079A (TSI Incorporated, Shoreview, MN, USA) as previously reported [52], and the particle diameter was $0.2-0.3 \mu \mathrm{m}$. The concentration of bacteria in the aerosol $(20 \mathrm{~cm}$ above the ground of the cages) was assessed every 15 mins using plate sedimentation method, and a proper amount of aerosolized bacteria was replenished every 15 mins. Chickens exposed in exported PBS without bacteria were used as a control group $(n=20)$. At $1,3,5,7$ and 14 days post infection (dpi), four chickens in each group were randomly selected, and the total mRNA of lungs and spleens was isolated using MiniBEST Universal RNA Extraction Kit (TaKaRa, Dalian, China). The expression levels of interleukin (IL)-1 $\beta$, IL-6, IL-8 and tumor necrosis factor (TNF)- $\alpha$ were detected by real-time reverse transcription (RT)-PCR. The gapdh gene was used as the internal control [53]. The primers were as follows: gapdh-f, 5'TCTCCATGGTGGTGAAGACA-3', gapdh-r, $5^{\prime}$ GACGTGCAGCAGGAACACTA-3'; IL-1 $\beta-\mathrm{f}, \quad 5^{\prime}-$ GGATTCTGAGCACACCACAGT-3', IL-1 $\beta-\mathrm{r}, \quad 5^{\prime}$ TCTGGTTGATGTCGAAGATGTC-3'; IL-6-f, $5^{\prime}$ ATCCGGCAGATGGTGATAAA-3', IL-6-r, $\quad 5^{\prime}$ CCCTCACGGTCTTCTCCATA-3'; IL-8-f, ${ }^{\prime}$ ' GCAAGGTAGGACGCTGGTAA-3', IL-8-r $5^{\prime}$ CCAAGCACACCTCTCTTCCA-3'; TNF- $\alpha-f, \quad 5^{\prime}-$ CTTCTGAGGCATTTGGAAGC-3', TNF- $\alpha-\mathrm{r} \quad 5^{\prime}$ ACTGGGCGGTCATAGAACAG-3'. Each assay was carried out with at least three biological replicates. After the experiment, the chickens were euthanized and underwent harmless treatment according to the regulations from Hubei Provincial Animal Care and Use Committee.

\section{Statistical analysis}

To test the bacterial loads in the bioaerosols, the bacteria count in each henhouse was calculated as the mean from five sampling sites, and the bacteria counts at different times were compared using Student's $t$-test. To evaluate the inflammatory responses induced by aerosolized CoNS, the relative transcript abundance levels of inflammatory cytokines were calculated using the $2^{-\Delta \Delta \mathrm{CT}}$ method and the expression levels at different times were compared using Student's $t$-test. A $p$-value $<0.05$ was considered statistically significant.

\section{Abbreviations}

CLSI: Clinical and Laboratory Standards Institute; CoNS: Coagulase-negative staphylococci; dpi: Days post-infection; IL: Interleukin; MIC: Minimum inhibitory concentration; MRCoNS: Methicillin-resistant CoNS; MRSA: Methicillin-resistant S. aureus; PBS: Phosphate-buffered saline; TNF: Tumor necrosis factor; VRSA: Vancomycin-resistant S. aureus

\section{Acknowledgements}

Not applicable.

\section{Authors' contributions}

$Y L, G W$, and TZ participated in the conception and design of the study. $Y L$, QLu, and YC performed the farm and laboratory work. YC, HS, and TZ analyzed the data and wrote the manuscript. QLuo and HS contributed to the analysis and helped in the manuscript discussion. All authors read and approved the final manuscript.

\section{Funding}

This work was funded by National Key Research and Development Plan of China (2016YFD0500505) and China Agriculture Research System (CARS-41G13). The funding bodies had no role in the design of the study, data collection and analysis, interpretation of data, or in writing the manuscript.

\section{Availability of data and materials}

The datasets generated and analysed during the current study are available from the corresponding author on reasonable request.

\section{Ethics approval and consent to participate}

The protocols of experimentation on animals were approved by the Hubei Provincial Animal Care and Use Committee (approval number SCXK 20180022). The animals used in this study were derived from commercial sources, and the owner consent was not required. In this study, the collections of bioaerosol samples were approved by the owners of these henhouses. Nasal swabs were from the farmers, and written informed consent was obtained from these poultry farmers.

Consent for publication

Not applicable.

\section{Competing interests}

The authors declare that they have no competing interests.

Received: 12 August 2019 Accepted: 20 January 2020

Published online: 28 January 2020

\section{References}

1. Widerstrom M, Wistrom J, Sjostedt A, Monsen T. Coagulase-negative staphylococci: update on the molecular epidemiology and clinical presentation, with a focus on Staphylococcus epidermidis and Staphylococcus saprophyticus. Eur J Clin Microbiol Infect Dis. 2012; 31(1):7-20. 
2. Heilmann C, Ziebuhr W, Becker K. Are coagulase-negative staphylococci virulent? Clin Microbiol Infect. 2019;25(9):1071-80.

3. Okoli CE, Njoga EO, Enem SI, Godwin EE, Nwanta JA, Chah KF. Prevalence, toxigenic potential and antimicrobial susceptibility profile of Staphylococcus isolated from ready-to-eat meats. Vet World. 2018;11(9):1214-21.

4. Mendes RE, Sader HS, Castanheira M, Flamm RK. Distribution of main grampositive pathogens causing bloodstream infections in United States and European hospitals during the SENTRY antimicrobial surveillance program (2010-2016): concomitant analysis of oritavancin in vitro activity. J Chemother. 2018:30(5):280-9.

5. Ranjit E, Raghubanshi BR, Maskey S, Parajuli P. Prevalence of bacterial Vaginosis and its association with risk factors among nonpregnant women: a hospital based study. Int J Microbiol. 2018;2018:8349601.

6. Stepien-Pysniak D, Wilczynski J, Marek A, Smiech A, Kosikowska U, Hauschild T. Staphylococcus simulans associated with endocarditis in broiler chickens. Avian Pathol. 2017;46(1):44-51.

7. Kawano J, Shimizu A, Saitoh Y, Yagi M, Saito T, Okamoto R. Isolation of methicillin-resistant coagulase-negative staphylococci from chickens. J Clin Microbiol. 1996;34(9):2072-7.

8. McNamee PT, Smyth JA. Bacterial chondronecrosis with osteomyelitis ('femoral head necrosis') of broiler chickens: a review. Avian Pathol. 2000; 29(4):253-70.

9. Awan MA, Matsumoto M. Heterogeneity of staphylococci and other bacteria isolated from six-week-old broiler chickens. Poult Sci. 1998;77(7):944-9.

10. Bhargava K, Zhang Y. Characterization of methicillin-resistant coagulasenegative staphylococci (MRCoNS) in retail meat. Food Microbiol. 2014;42: 56-60.

11. Pourakbari B, Mahmoudi S, Moradzadeh M, Mahzari M, Ashtiani MTH, Tanzifi $P$, Mamishi S. Antimicrobial resistance patterns of the gram-positive Bacteria isolated from children with bloodstream infection in an Iranian referral hospital: a 6-year study. Infect Disord Drug Targets. 2018;18(2):136-44.

12. Gkentzi D, Kolyva S, Spiliopoulou I, Marangos M, Dimitriou G. Treatment options for persistent coagulase negative staphylococcal bacteremia in neonates. Curr Pediatr Rev. 2016;12(3):199-208

13. Zlatian O, Balasoiu AT, Balasoiu M, Cristea O, Docea AO, Mitrut R, Spandidos DA, Tsatsakis AM, Bancescu G, Calina D. Antimicrobial resistance in bacterial pathogens among hospitalised patients with severe invasive infections. Exp Ther Med. 2018:16(6):4499-510.

14. Piessens V, Van Coillie E, Verbist B, Supre K, Braem G, Van Nuffel A, De Vuyst $L$, Heyndrickx M, De Vliegher S. Distribution of coagulase-negative Staphylococcus species from milk and environment of dairy cows differs between herds. J Dairy Sci. 2011;94(6):2933-44.

15. McGuinness WA, Malachowa N, DeLeo FR. Vancomycin resistance in Staphylococcus aureus. Yale J Biol Med. 2017;90(2):269-81.

16. Omara ST. MIC and MBC of honey and gold nanoparticles against methicillin-resistant (MRSA) and vancomycin-resistant (VRSA) coagulasepositive $\mathrm{S}$. aureus isolated from contagious bovine clinical mastitis. I Genet Eng Biotechnol. 2017;15(1):219-30.

17. Lakhundi S, Zhang K. Methicillin-Resistant Staphylococcus aureus: Molecular Characterization, Evolution, and Epidemiology. Clin Microbiol Rev. 2018;31(4). https://doi.org/10.1128/CMR.00020-18.

18. Rosen $\mathrm{K}$, Roesler U, Merle R, Friese A. Persistent and transient airborne MRSA colonization of piglets in a newly established animal model. Front Microbiol. 2018;9:1542.

19. Li L, Chen Z, Guo D, Li S, Huang J, Wang X, Yao Z, Chen S, Ye X. Nasal carriage of methicillin-resistant coagulase-negative staphylococci in healthy humans is associated with occupational pig contact in a dose-response manner. Vet Microbiol. 2017;208:231-8.

20. Oppliger A, Charriere N, Droz PO, Rinsoz T. Exposure to bioaerosols in poultry houses at different stages of fattening; use of real-time PCR for airborne bacterial quantification. Ann Occup Hyg. 2008;52(5):405-12

21. Just NA, Letourneau V, Kirychuk SP, Singh B, Duchaine C. Potentially pathogenic bacteria and antimicrobial resistance in bioaerosols from cage-housed and floor-housed poultry operations. Ann Occup Hyg. 2012:56(4):440-9.

22. Walser SM, Gerstner DG, Brenner B, Bunger J, Eikmann T, Janssen B, Kolb S, Kolk $A$, Nowak D, Raulf M, et al. Evaluation of exposure-response relationships for health effects of microbial bioaerosols - a systematic review. Int J Hyg Environ Health. 2015;218(7):577-89.

23. Anderson BD, Lednicky JA, Torremorell M, Gray GC. The use of bioaerosol sampling for airborne virus surveillance in swine production facilities: a mini review. Front Vet Sci. 2017:4:121.
24. Predicala BZ, Urban JE, Maghirang RG, Jerez SB, Goodband RD. Assessment of bioaerosols in swine barns by filtration and impaction. Curr Microbiol. 2002;44(2):136-40

25. Kanci A, Wawegama NK, Marenda MS, Mansell PD, Browning GF, Markham PF. Reproduction of respiratory mycoplasmosis in calves by exposure to an aerosolised culture of mycoplasma bovis. Vet Microbiol. 2017;210:167-73.

26. Plewa $\mathrm{K}$, Lone $\mathrm{E}$. Analysis of airborne contamination with bacteria and moulds in poultry farming: a case study. Pol J Environ Stud. 2011;20(3):725-31.

27. Chinivasagam HN, Tran T, Maddock L, Gale A, Blackall PJ. The aerobiology of the environment around mechanically ventilated broiler sheds. J Appl Microbiol. 2010;108(5):1657-67.

28. Schulz J, Formosa L, Seedorf J, Hartung J. Measurement of culturable airborne staphylococci downwind from a naturally ventilated broiler house. Aerobiologia. 2011;27:311-8.

29. Skora J, Matusiak K, Wojewodzki P, Nowak A, Sulyok M, Ligocka A, Okrasa M, Hermann J, Gutarowska B. Evaluation of microbiological and chemical contaminants in poultry farms. Int J Environ Res Public Health. 2016;13(2):192.

30. Henningson E, Ahlberg M. Evaluation of microbiological aerosol samplers: a review. J Aerosol Sci. 1994;25(8):1459-92.

31. Abdel Halim RM, Kassem NN, Mahmoud BS. Detection of biofilm producing staphylococci among different clinical isolates and its relation to methicillin susceptibility. Open Access Maced J Med Sci. 2018;6(8):1335-41.

32. Simjee S, McDermott PF, White DG, Hofacre C, Berghaus RD, Carter PJ, Stewart L, Liu T, Maier M, Maurer JJ. Antimicrobial susceptibility and distribution of antimicrobial-resistance genes among Enterococcus and coagulase-negative Staphylococcus isolates recovered from poultry litter. Avian Dis. 2007;51(4):884-92.

33. Boamah VE, Agyare C, Odoi H, Adu F, Gbedema SY, Dalsgaard A. Prevalence and antibiotic resistance of coagulase-negative staphylococci isolated from poultry farms in three regions of Ghana. Infect Drug Resist. 2017;10:175-83.

34. Huber H, Ziegler D, Pfluger V, Vogel G, Zweifel C, Stephan R. Prevalence and characteristics of methicillin-resistant coagulase-negative staphylococci from livestock, chicken carcasses, bulk tank milk, minced meat, and contact persons. BMC Vet Res, 2011:7:6.

35. Becker K, Heilmann C, Peters G. Coagulase-negative staphylococci. Clin Microbiol Rev. 2014;27(4):870-926.

36. Blot SI, Depuydt P, Annemans L, Benoit D, Hoste E, De Waele JJ, Decruyenaere J, Vogelaers D, Colardyn F, Vandewoude KH. Clinical and economic outcomes in critically ill patients with nosocomial catheterrelated bloodstream infections. Clin Infect Dis. 2005;41(11):1591-8.

37. Frickmann H, Hahn A, Skusa R, Mund N, Viehweger V, Koller T, Koller K, Schwarz NG, Becker K, Warnke P, et al. Comparison of the etiological relevance of Staphylococcus haemolyticus and Staphylococcus hominis. Eur J Clin Microbiol Infect Dis. 2018;37(8):1539-45.

38. Loughrey A, Millar BC, Goldsmith CE, Rooney PJ, Moore JE. Emergence of community-associated MRSA (CA-MRSA) in Northern Ireland. Ulster Med J. 2007;76(2):68-71.

39. Robinson DA, Enright MC. Multilocus sequence typing and the evolution of methicillin-resistant Staphylococcus aureus. Clin Microbiol Infect. 2004;10(2):92-7.

40. Ye X, Wang X, Fan Y, Peng Y, Li L, Li S, Huang J, Yao Z, Chen S. Genotypic and phenotypic markers of livestock-associated methicillin-resistant Staphylococcus aureus CC9 in humans. Appl Environ Microbiol. 2016;82(13): 3892-9.

41. Osman K, Badr J, Al-Maary KS, Moussa IM, Hessain AM, Girah ZM, AboShama UH, Orabi A, Saad A. Prevalence of the antibiotic resistance genes in coagulase-positive-and negative-Staphylococcus in chicken meat retailed to consumers. Front Microbiol. 2016;7:1846.

42. Heinze K, Kabeto M, Martin ET, Cassone M, Hicks L, Mody L. Predictors of methicillin-resistant Staphylococcus aureus and vancomycin-resistant enterococci co-colonization among nursing facility patients. Am J Infect Control. 2019:47(4):415-20.

43. Wu B, Qi Q, Zhang X, Cai Y, Yu G, Lv J, Gao L, Wei L, Chai T. Dissemination of Escherichia coli carrying plasmid-mediated quinolone resistance (PMQR) genes from swine farms to surroundings. Sci Total Environ. 2019;665:33-40.

44. Broom LJ, Kogut MH. Inflammation: friend or foe for animal production? Poult Sci. 2018:97(2):510-4

45. Liu JB, Yan HL, Zhang Y, Hu YD, Zhang HF. Effects of stale maize on growth performance, immunity, intestinal morphology and antioxidant capacity in broilers. Asian-Australas J Anim Sci. 2019. https:/doi.org/10.5713/ajas.19.0224. 
46. Klasing KC. Nutrition and the immune system. Br Poult Sci. 2007;48(5): 525-37.

47. Faure M, Chone F, Mettraux C, Godin JP, Bechereau F, Vuichoud J, Papet I, Breuille $\mathrm{D}$, Obled C. Threonine utilization for synthesis of acute phase proteins, intestinal proteins, and mucins is increased during sepsis in rats. J Nutr. 2007;137(7):1802-7.

48. Sandberg FB, Emmans GC, Kyriazakis I. A model for predicting feed intake of growing animals during exposure to pathogens. J Anim Sci. 2006;84(6): 1552-66.

49. Goldstein RR, Kleinfelter L, He X, Micallef SA, George A, Gibbs SG, Sapkota AR. Higher prevalence of coagulase-negative staphylococci carriage among reclaimed water spray irrigators. Sci Total Environ. 2017;595:35-40.

50. CLSI. Performance Standards for Antimicrobial Susceptibility Testing M100S. 26th ed; 2017

51. Bitrus AA, Zunita Z, Bejo SK, Othman S, Nadzir NA. In vitro transfer of methicillin resistance determinants mecA from methicillin resistant Staphylococcus aureus (MRSA) to methicillin susceptible Staphylococcus aureus (MSSA). BMC Microbiol. 2017;17(1):83.

52. Fu Y, Wang Z, Lu B, Zhao S, Zhang Y, Zhao Z, Zhang C, Li J, Zhou B, Guo Z, et al. Immune response and differentially expressed proteins in the lung tissue of BALB/C mice challenged by aerosolized Brucella melitensis 5. J Int Med Res. 2018:46(11):4740-52.

53. Liu JB, Yan HL, Cao SC, Hu YD, Zhang HF. Effects of absorbents on growth performance, blood profiles and liver gene expression in broilers fed diets naturally contaminated with aflatoxin. Asian Australas J Anim Sci. 2020;33(2):294304.

\section{Publisher's Note}

Springer Nature remains neutral with regard to jurisdictional claims in published maps and institutional affiliations.

Ready to submit your research? Choose BMC and benefit from:

- fast, convenient online submission

- thorough peer review by experienced researchers in your field

- rapid publication on acceptance

- support for research data, including large and complex data types

- gold Open Access which fosters wider collaboration and increased citations

- maximum visibility for your research: over $100 \mathrm{M}$ website views per year

At $\mathrm{BMC}$, research is always in progress.

Learn more biomedcentral.com/submissions 